\title{
KADAR TRIGLISERIDA, KOLESTEROL, DAN LEMAK ABDOMEN AYAM BROILER YANG DIBERI CAIRAN SAUERKRAUT DALAM AIR MINUM
}

\author{
I. Dian Kinasih ${ }^{1}$ dan T. Sopandi ${ }^{2}$ \\ ${ }^{1}$ Mahasiwa Prodi Biologi FMIPA Universitas PGRI Adi Buana Surabaya \\ Renz_354@yahoo.com \\ ${ }^{2}$ Staf Pengajar Prodi Biologi FMIPA Universitas PGRI Adi Buana Surabaya \\ tatang.sopandi.1963@gmail.com
}

\begin{abstract}
This study aims to prove a liquid of sauerkraut in the drinking water of broilers can lower triglyceride content, cholesterol content, and abdominal fat chicken broiler. Twenty four broiler chickens aged 1 day an average of 25-35 g/ tail. Broiler chickens were randomly divided into 4 groups and repeated 6 times. Each group was given liquid of sauerkraut in drinking water with concentrations of $0,0.5,1.0,1.5 \mathrm{ml} / \mathrm{L}$ for 35 days. The results of the study treatment sauerkraut liquid in drinking water concentration of $1.0 \mathrm{ml} / \mathrm{L}$ and $1.5 \mathrm{ml} / \mathrm{L}$ have a significant effect $(\mathrm{P}<0.05)$ on triglyceride content, cholesterol content, and abdominal fat of broiler chickens. Giving sauerkraut liquid on triglyceride content broiler concentration of $1.0 \mathrm{ml} / \mathrm{L}$ and $1.5 \mathrm{ml} / \mathrm{L}$ significantly $(\mathrm{P}<0.05)$ lower triglyceride content compared with broilers without liquid of sauerkraut. Giving liquid sauerkraut on cholesterol content of broiler concentration $1.0 \mathrm{ml} / \mathrm{L}$ and $1.5 \mathrm{ml} / \mathrm{L}$ significantly $(\mathrm{P}<0.05)$ lower cholesterol content compared with broilers without liquid of sauerkraut. Giving liquid of sauerkraut against abdominal fat of broilers concentration of $1.0 \mathrm{ml} / \mathrm{L}$ and $1.5 \mathrm{ml} / \mathrm{L}$ significantly $(\mathrm{P}<0.05)$ lower cholesterol content compared with broilers without liquid of sauerkraut. It can be concluded that the drinking water in sauerkraut liquid for broiler chicken lower triglyceride content, cholesterol content, and abdominal fat of broiler chickens at a concentration of $1.0-1.5 \mathrm{ml} / \mathrm{L}$ respectively, still at $69.4 \%-79.2 \%, 32,9 \%,-39.4 \%$, and $44.7 \%-50.3 \%$. The measure of sauerkraut liquid in drinking water for the purpose of reduction in triglyceride content, cholesterol content, and abdominal fat of broiler chicken meat can be used at a concentration of 1.0 to $1.5 \mathrm{ml} / \mathrm{L}$.
\end{abstract}

Keyword: broiler chicken meat, sauerkraut liquid, triglyceride content, cholesterol content, and abdominal fat.

\section{PENDAHULUAN}

Peningkatan jumlah penduduk Indonesia berdampak pada peningkatan kebutuhan bahan makanan terutama protein hewani. Daging ayam memberi sumbangan yang sangat berarti dalam memenuhi kebutuhan protein hewani (Prayitno,2003). Kontribusi daging asal unggas mengalami peningkatan dari $20 \%$ pada tahun 1970 menjadi 65\% pada tahun 2008 (Fadilah, 2013).

Penggunaan antibiotik atau antimikrobial sebagai bahan aditif dalam pakan telah berlangsung lebih dari 40 tahun. Senyawa antibiotik digunakan sebagai growth promotor dalam jumlah yang relatif kecil namun dapat meningkatkan efisiensi pakan (feed efficiency) dan reproduksi ternak. Akan tetapi penggunaan antibiotic yang berkelanjutan dan tidak sesuai anjuran dapat menimbulkan masalah baru, yaitu munculnya bakteri-bakteri yang kebal terhadap antibiotik. Akhir-akhir ini penggunaan antibiotik di beberapa negara telah dibatasi penggunaannya. Hal ini disebabkan oleh beberapa faktor, antara lain : 1) kemungkinan hadirnya residu antibiotik dalam produk yang dihasilkan akan menjadi racun bagi konsumen dan, 2) dapat menyebabkan mikroorganisme yang ada dalam tubuh manusia maupun ternak (terutama bakteri-bakteri patogen seperti Salmonella, E. coli dan Clostridium perfringens) menjadi resisten terhadap antibiotik tertentu (Král M. et.al, 2012).

Mikroorganisme yang dapat berfungsi sebagai probiotik berupa bakteri, kapang dan khamir. Namun bakteri merupakan mikroorganisme yang paling banyak digunakan sebagai probiotik (Raja , et al., 2011). Tidak semua bakteri baik dapat dijadikan sebagai probiotik, salah satu bakteri yang berperan sebagai probiotik adalah bakteri asam laktat (BAL) (Trisna,et al.,2012).

Selanjutnya Setiawan (1999) melaporkan bahwa probiotik tidak meninggalkan residu dan tidak mengakibatkan resistensi, sehingga aman bagi manusia. Sauerkraut merupakan salah satu pangan produk fermentasi yang telah dikenal bermanfaat untuk kesehatan. Hampir semua sayuran dapat difermentasi melalui proses alami, karena sayuran merupakan tempat hidup beberapa jenis bakteri asam laktat. Sauerkraut merupakan fermentasi sayuran dari kubis dan garam pada suhu $18^{\circ} \mathrm{C}$ selama 2 bulan. Hasil fermentasi kubis memiliki rasa dan flavor asam, sedangkan garam dapat menstimulasi pertumbuhan bakteri asam laktat dan menghambat beberapa bakteri yang tidak diinginkan, serta aktivitas pektinase (Sopandi, et al., 2014).

Kajian mengenai efektifitas penggunaan sauerkraut sebagai prebiotik terhadap kadar 
trigliserida, kolesterol,dan lemak abdomenal ayam brolier belum banyak diungkap dan di publikasikan secara luas.

\section{METODE PENELITIAN}

Penelitian mengenai kadar trigliserida, kolesterol, dan lemak abdomen ayam broiler yang diberi cairan sauerkraut dalam air minum dilakukan sebagai upaya menghasilkan kadar trigliserida, kolesterol, dan lemak abdomen yang rendah pada ayam broiler yang diberi cairan sauerkaraut dalam air minum telah dilakukan secara eksperimental di laboratorium.

\section{Pembuatan cairan sauerkraut pada ayam broiler yang di campur dalam air minum \\ Melayukan kubis selama 1 malam, lalu membuang daun kubis bagian ,lalu mencuci bersih. Kemudian memotong tipis - tipis $\pm 2-3 \mathrm{~mm}$, mencampur dengan garam 22,5 gram, aduk hingga rata kemudian masukkan ke baskom kecil. Menutup toples dengan penutupnya, dan membiarkan penggaraman selama 2 minggu pada suhu ruangan, setelah itu pisahkan cairannya. Memasukkan padatan sauerkraut tersebut ke dalam botol atau wadah yang telah disediaakan.}

\section{Pemberian cairan sauerkraut pada ayam broiler dalam air minum}

Sebanyak 24 ekor ayam broiler DOC dari strain CP707 dibagi menjadi 4 kelompok perlakuan, masing-masing kelompok terdapat 6 ekor ayam broiler dan dipelihara selama 35 hari. setelah 2 minggu memindahkan ayam broiler ke kandang yang lebih besar. Menyiapkan sauerkraut, setiap kelompok mendapat perlakuan dengan menambahkan air sauerkraut dalam air minum. Setelah itu memberi ayam dengan perlakuan yaitu cairan sauerkraut dengan konsentrasi $0 \mathrm{ml} / \mathrm{L}, 0,5$ $\mathrm{ml} / \mathrm{L}, \quad 1 \mathrm{ml} / \mathrm{L}$, dan $1,5 \mathrm{ml} / \mathrm{L}$. Memberikan pakan diberikan secara ad libitum dengan pakan komersil . selanjtnya berikan cairan sauerkraut sesuai dengan perlakuan . Mengatur suhu ruangan $25-27^{\circ} \mathrm{C}$. Pada hari pertama memberi air gula. Sedangkan untuk pemberian vaksin pada hari ke-3 berupa tetes mata, pada hari ke-14 berupa injeksi dada untuk menjaga imunitas ayam

\section{Lemak Abdomen}

Pengukuran bobot lemak abdomen dilakukan dengan cara menimbang lemak yang terdapat pada sekeliling gizzard dan lapisan yang menempel antara otot abdomen serta usus. Persentase lemak abdomen diperoleh dengan dibandingkan bobot hidup dikalikan 100 (Witantra, 2011).

\section{Analisis Kadar Kolesterol}

Pengukuran kadar kolesterol dilakukan berdasarkan metode Lieberman Burchard (Kleiner Dotti, 1962). Cara kerjanya yaitu dengan menimbang sampel sebanyak 0,2 g yang dimasukkan kedalam tabung sentrifus berskala 15 . Tambahkan campuran alcohol eter 3:1 sebanyak 12 $\mathrm{ml}$ dan diaduk hingga homogen. Diamkan larutan sambil dikocok sesekali selama 30 menit. Bilas pengaduk dengan alkohol eter 3:1 dan setarakan menjadi $15 \mathrm{ml}$ kemudian disentrifuse dengan kecepatan 3000rpm selama 15 menit. Supernatant dipindahkan ke dalam gelas piala $50 \mathrm{ml}$ dan dipanaskan dalam penangas air hingga kering. Ekstrak residu dilarutkan dengan $25 \mathrm{ml}$ kloroform sedikit demi sedikit atau dicuci sebanyak dua kali dan dimasukkan dalam tabung reaksi $10 \mathrm{ml}$ untuk disetarakan volumenya menjadi $5 \mathrm{ml}$. Masukkan juga kolesterol standar $5 \mathrm{ml}(0,4 \mathrm{mg}$ kolesterol dalam $5 \mathrm{ml}$ kloroform) kedalam tabung reaksi yang lain. Setelah itu tambahkan $2 \mathrm{ml}$ asetat anhidrida dan $1000 \mu \mathrm{lH}_{2} \mathrm{SO}_{4}$ pekat,. Selanjutnya dilakukan pembacaan dengan menggunakan spektrefotometer pada panjang gelombang $420 \mathrm{~nm}$ (Fenita et all., 2012).

\section{Analisis Kadar Trigliserida}

Menggunakan metode warna enzimatik (SHM, 2000). Sampel daging diambil sebanyak $1 \mathrm{~g}$, dimasukkan ke dalam tabung reaksi kemudian tambahkan $10 \mathrm{ml}$ Aceton Etanol. Pelarut Aceton Etanol dengan sampel diuapkan didalam waterbath pada suhu $60^{\circ} \mathrm{C}$ sehingga volume pelarut separuh dari volume awal atau diuapkan selama 15 menit. Pelarut yang tinggal disaring dengan menggunakan kertas Whatman 41. Residu sampel dilarutkan kembali dengan Aceton Etanol sebanyak $5 \mathrm{ml}$, kemudian diuapkan kembali pada suhu $60^{\circ} \mathrm{C}$ selama 10 menit. Pelarut yang tersisa disaring dan diulang sekali lagi. Hasil ekstraksi dipanaskan di dalam waterbath pada suhu $60^{\circ} \mathrm{C}$ sehingga volume pelarut yang tertinggal adalah $1 \mathrm{ml}$. Larutan ekstraksi ini kemudian dianalisa kadar kolesterolnya. Sebanyak $1 \mathrm{ml}$ reagent (kit) trigliserida dipipetkan ke dalam tabung reaksi kemudian ditambahkan serum atau hasil ekstraksi sebanyak 0,01 ml.Larutan kemudian diinkubasi selama 20 menit di dalam waterbath pada suhu $37^{\circ} \mathrm{C}$ sehingga warna larutan berubah menjadi warna lembayung. Pembuatan blanko: $1 \mathrm{ml}$ kit trigliserida dipipetkan ke dalam tabung reaksi. Blanko dibuat sebagai pembanding. Setiap satu analisa dibuatkan satu seri blanko. Blanko dimasukkan ke dalam sel spektrofotometer setelah diarahkan pada panjang gelombang $520 \mathrm{~nm}$.

\section{Analisis Statistika}

Data hasil pengamatan kadar trigliserida, kolesterol, dan lemak abdomen dianalisis dengan uji analisia varian sesuai dengan rancangan percobaan Rancangan Acak Lengkap ( RAL ) . Data hasil pengataman tersebut, dianalisis dengan uji lanjut beda nyata jujur tukey menggunakan uji tukey pada tingkat signifikasi $5 \%$. 


\title{
HASIL PENELITIAN
}

\author{
Lemak Abdomen
}

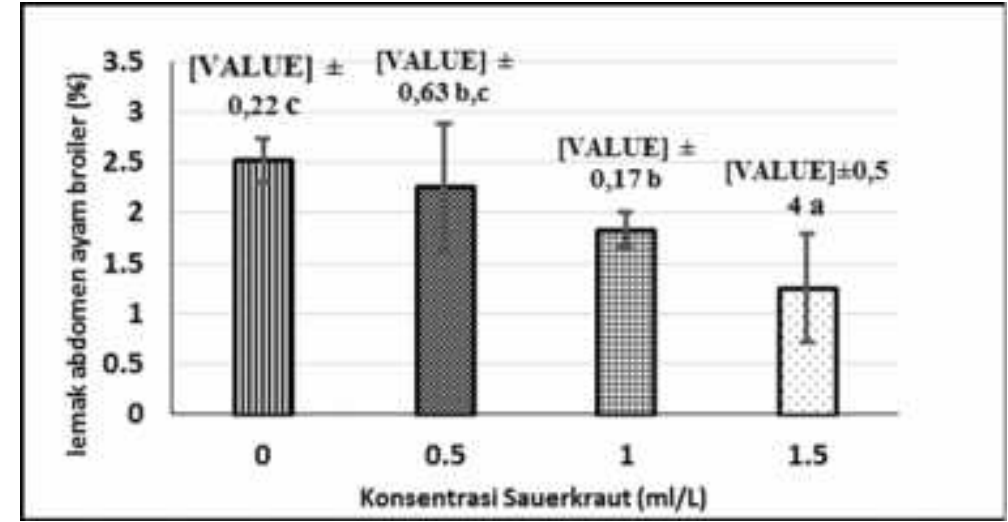

Gambar 1. Lemak Abdomen Daging Ayam Broiler yang diberi Sauerkraut

Hasil penelitian gambar 1 menunjukkan bahwa lemak abdomen pada ayam broiler yang diberi perlakuan konsentrasi $1,5 \mathrm{ml} / \mathrm{L}(1,25 \pm 0,54 \%)$ signifikan $(\mathrm{P}<0,05)$ lebih rendah dibandingkan dengan lemak abdomen ayam broiler yang diberi perlakuan $1 \mathrm{ml} / \mathrm{L}(1,83 \pm 0,17 \%), 0,5 \mathrm{ml} / \mathrm{L}(2,26 \pm$ $0,63 \%)$, dan $0 \mathrm{ml} / \mathrm{L}(2,52 \pm 0,22 \%)$. Lemak abdomen ayam broiler yang diberi perlakuan konsentrasi $1 \mathrm{ml} / \mathrm{L} \quad(1,83 \pm 0,17 \%)$ signifikan $\mathrm{P}(<0,05)$ lebih rendah dibandingkan dengan lemak abdomen perlakuan $0,5 \mathrm{ml} / \mathrm{L}(2,26 \pm 0,63 \%)$ dan 0 $\mathrm{ml} / \mathrm{L} \quad(2,52 \pm 0,22 \%)$. Lemak abdomen ayam broiler yang diberi perlakuan $0,5 \mathrm{ml} / \mathrm{L} \quad(2,26 \pm$ $0,63 \%)$ tidak berbeda signifikan $\mathrm{P}(<0,05)$ dibandingkan dengan lemak abdomen yang diberi perlakuan $0 \mathrm{ml} / \mathrm{L}(2,52 \pm 0,22 \%)$.

\section{Kadar Kolesterol}

Hasil penelitian gambar 2 menunjukkan bahwa pemberian sauerkraut dalam air minum ayam broiler yang diberi perlakuan konsentrasi $1,5 \mathrm{ml} / \mathrm{L}(39,2 \pm$ $2,86 \mathrm{mg} / \mathrm{g})$ tidak berbeda signifikan $\mathrm{P}(<0,05)$ dibandingkan dengan kadar kolesterol daging ayam broiler konsentrasi $1 \mathrm{ml} / \mathrm{L}(45,4 \pm 6,46 \mathrm{mg} / \mathrm{g})$, namun signifikan $(\mathrm{P}<0,05)$ lebih rendah dibandingkan dengan kadar kolesterol daging ayam broiler yang diberi perlakuan konsentrasi $0,5 \mathrm{ml} / \mathrm{L}$ $(58,4 \pm 6,28 \mathrm{mg} / \mathrm{g})$ dan $0 \mathrm{ml} / \mathrm{L}(64,7 \pm 8,13 \mathrm{mg} / \mathrm{g})$. Pemberian sauerkraut dalam air minum ayam broiler yang diberi perlakuan konsentrasi $1 \mathrm{ml} / \mathrm{L}(45,4 \pm$ $6,46 \mathrm{mg} / \mathrm{g})$ signifikan $(\mathrm{P}<0,05)$ lebih rendah dibandingkan dengan kadar kolesterol daging ayam broiler yang diberi perlakuan konsentrasi $0,5 \mathrm{ml} / \mathrm{L}$ $(58,4 \pm 6,28 \mathrm{mg} / \mathrm{g})$ dan $0 \mathrm{ml} / \mathrm{L}(64,7 \pm 8,13 \mathrm{mg} / \mathrm{g})$. Pemberian sauerkraut dalam air minum ayam broiler yang diberi perlakuan konsentrasi $0,5 \mathrm{ml} / \mathrm{L}(58,4 \pm$ $6,28 \mathrm{mg} / \mathrm{g})$ tidak berbeda signifikan $(\mathrm{P}<0,05)$ dibandingan dengan kadar kolesterol daging ayam broiler $0 \mathrm{ml} / \mathrm{L}(64,7 \pm 8,13 \mathrm{mg} / \mathrm{g})$.

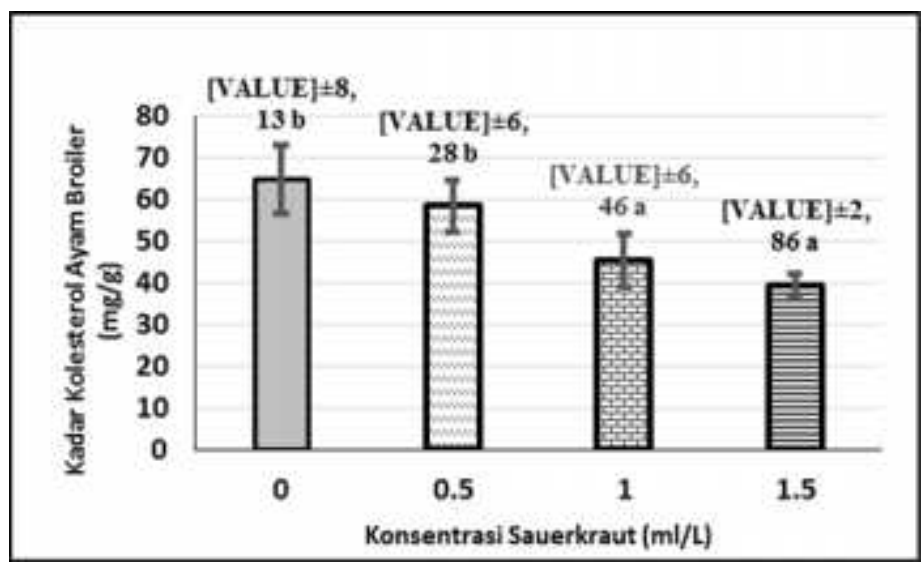

Gambar 2. Kadar Kolesterol Daging Ayam Broiler yang diberi Sauerkraut

\section{Kadar Trigliserida}

Hasil penelitian gambar 3 menunjukkan bahwa kadar trigliserida daging ayam broiler yang diberi perlakuan pada konsentrasi 1,5 $\mathrm{ml} / \mathrm{L}(193,5 \pm 17,3$ $\mathrm{mg} / \mathrm{g})$ tidak berbeda signifikan $(\mathrm{P}<0,05)$ dibandingkan dengan kadar trigliserida daging ayam 
broiler konsentrasi $1 \mathrm{ml} / \mathrm{L}(281,3 \pm 46,1 \mathrm{mg} / \mathrm{g})$, namun signifikan $(\mathrm{P}<0,05)$ lebih rendah dibandingkan dengan kadar trigliserida daging ayam broiler konsentrasi $0,5 \mathrm{ml} / \mathrm{L}(633,2 \pm 64,2 \mathrm{mg} / \mathrm{g})$ dan $0 \mathrm{ml} / \mathrm{L}(929,0 \pm 236,4 \mathrm{mg} / \mathrm{g})$. Kadar trigliserida daging ayam broiler yang diberi perlakuan pada konsentrasi $1 \mathrm{ml} / \mathrm{L}(281,3 \pm 46,1 \mathrm{mg} / \mathrm{g})$ signifikan $(\mathrm{P}<0,05)$ lebih rendah dibandingkan dengan kadar trigliserida daging ayam broiler konsentrasi $0,5 \mathrm{ml} / \mathrm{L}$ $(633,2 \pm 64,2 \mathrm{mg} / \mathrm{g})$ dan $0 \mathrm{ml} / \mathrm{L}(929,0 \pm 236,4$ $\mathrm{mg} / \mathrm{g})$. Kadar trigliserida daging ayam broiler yang diberi perlakuan pada konsentrasi $0,5 \mathrm{ml} / \mathrm{L}(633,2 \pm$ $64,2 \mathrm{mg} / \mathrm{g})$ signifikan $(\mathrm{P}<0,05)$ lebih rendah dibandingkan dengan kadar trigliserida daging ayam broiler konsentrasi $0 \mathrm{ml} / \mathrm{L}(929,0 \pm 236,4 \mathrm{mg} / \mathrm{g})$.

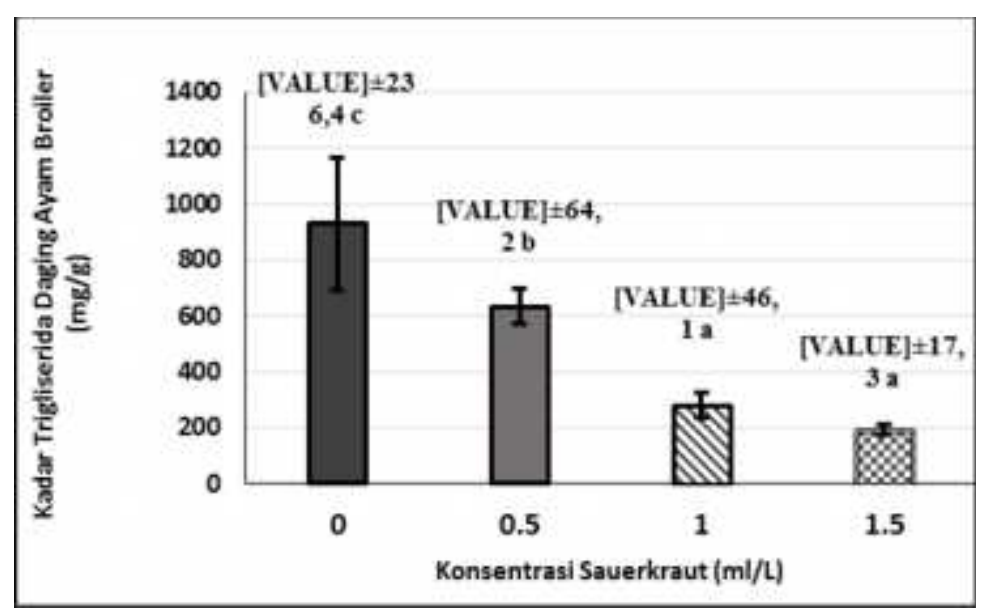

Gambar 3. Kadar Trigliserida Daging Ayam Broiler yang diberi Sauerkraut

\section{PEMBAHASAN}

Hasil penelitian ini menunjukkan bahwa pemberian sauerkraut dalam air minum ayam broiler berpengaruh signifikan $(\mathrm{P}<0,05)$ terhadap lemak abdomen ayam broiler. Pemberian cairan sauerkraut dalam air minum pada konsentrasi $0 \mathrm{ml}$ tidak berbeda signifikan terhadap $0,5 \mathrm{ml}$ dan konsentrasi $0,5 \mathrm{ml}$ tidak berbeda signifikan terhadap $1.0 \mathrm{ml}$, hal ini diduga karena perbedaan pemberian cairan sauerkraut dalam air minum tidak berbeda jauh, dan jumlah bateri yang terkadung dalam sauerkraut sedikit. Sedangkan Pemberian sauerkraut dalam air minum ayam broiler dengan konsentrasi $1,5 \mathrm{ml} / \mathrm{L}$ dan 1,0 $\mathrm{ml} / \mathrm{L}$ dapat menurunkan lemak abdomen masing-masing sebesar 50,4 \% dan 44,7 \%. Penurunan lemak abdomenal ayam broiler diduga disebabkan karena aktifitas bakteri asam laktat (BAL) yang mampu menurunkan kadar lemak abdomen dalam ayam broiler .

Hasil penelitian ini menunjukkan bahwa pemberian sauerkraut dalam air minum ayam broiler berpengaruh signifikan $(\mathrm{P}<0,05)$ terhadap kadar kolesterol daging ayam broiler. Pemberian sauerkraut dalam air minum ayam broiler dengan konsentrasi $1,5 \quad \mathrm{ml} / \mathrm{L}$ dan $1,0 \quad \mathrm{ml} / \mathrm{L}$ dapat menurunkan kadar kolesterol daging ayam broiler masing masing sebesar $39,4 \%$ dan $32,9 \%$. Penurunan tersebut di duga adanya aktivitas bakteri asam laktat (BAL) untuk metabolisme enzim bile salt hidrolase dalam reabsorbsi lemak dan garam empedu.

Hasil penelitian ini menunjukkan bahwa pemberian sauerkraut dalam air minum ayam broiler berpengaruh signifikan $(\mathrm{P}<0,05)$ terhadap kadar trigliserida daging ayam broiler. Pemberian sauerkraut dalam air minum ayam broiler dengan konsentrasi $1,5 \mathrm{ml} / \mathrm{L}$ dan $1,0 \mathrm{ml} / \mathrm{L}$ dapat menurunkan kadar trigliserida daging ayam broiler masing- masing sebesar $79,2 \%$ dan $69,4 \%$. Penurunan tersebut disebabkan adanya aktifitas bakteri asam laktat ( BAL ) yang mempengaruhi proses sintesis asam lemak di dalam tubuh ternak. Santoso et al., (1995) melaporkan bahwa pemberian probiotik dapat menurunkan lemak abdomen, kadar kolesterol, dan trigliserida karena probiotik secara efektif dapat menurunkan aktivitas asetil KoA karboksilase yaitu enzim yang berperan dalam laju sintesis asam lemak. Menurut Abu-Elheiga et al., (1995) menyatakan bahwa malonil KoA yang dihasilkan oleh asetil KoA karboksilase merupakan kunci metabolit dalam mengatur sintesis asam lemak dan oksidasi yang dapat dipengaruhi oleh perubahan pola makan serta aktivitas usus. Saputri, et.al., ( 2012 ) melaporkan bahwa bakteri asam laktat menghasilkan enzim Bile Salt Hydrolase yang menurunkan kadar kolesterol dan enzim lipase yang bisa menurunkan trigliserida karena kemampuannya dalam memutuskan asam lemak rantai panjang menjadi asam lemak rantai sedang dan rantai pendek sehingga mudah diserap dalam usus.

\section{KESIMPULAN}

Penelitian dapat disimpulkan bahwa pemberian cairan sauerkraut konsentrasi $1,0 \mathrm{ml} / \mathrm{L} \quad 1,5 \mathrm{ml} / \mathrm{L}$ 
dapat menurunkan kadar trigliserida, kolesterol, dan lemak abdomen ayam broiler.

\section{SARAN}

Takaran penggunaan sauerkraut dalam air minum untuk tujuan penurunkan kadar trigliserida, kadar kolesterol, dan lemak abdomen daging ayam broiler dapat digunakan di gunakan pada konsentrasi 1,0 $1,5 \mathrm{ml} / \mathrm{L}$.

\section{DAFTAR PUSTAKA}

Abu-Elheiga, L., Jayakumar, A., Baldini, A., Chirala,S.S. \& Wakil, S.J. 1995. Human acetyl-CoA carboxylase: Molecular cloning, characterization, chromosomal mapping, and evidence for two isoforms. Proc. Natl. Acad. Sci. 92: 4011-4015.

Fadilah, R. 2013. Super Lengkap Beternak Ayam Broiler. Jakarta ; Agromedia Pustaka

Kleiner I. S \& B. Dotti. 1962. Laboratory Instruction in Biochemistry. $6^{\text {th }} \mathrm{Ed}$. The C. V Mosby Co. New York.

Král M, Angelovicova M, dan Mrazova L. 2012. Application of Probiotics in Poultry Production . Slovak University of Agriculture in Nitra, Faculty of Biotechnology and Food Sciences, Department of Food Hygiene and Safety, 949 76-Nitra.

Prayitno, D,S dan Wahono, E,Y. 1997. Manajemen Ayam Ras Pedaging. Cetakan-1. Trubus Agriwidia. Ungaran
Santoso U.; Tanaka, K. \& Ohtani, S. (1995). Effect of dried Bacillus subtilis culture on growth, body composition and hepatic lipogenic enzyme activity in female broiler chicks. British Journal of Nutrition, Vol.74, No.4, (October 1995), pp.523-529, ISSN 00071145 .

Saputri F. 2012. Pengaruh Pemberian Probiotik Bakteri Asam Laktat (Bal) Pediococcus Pentosaceus Terhadap Keseimbangan Mikroflora Usus Dan 49 Trigliserida Daging Itik Pitalah. Laporan Penelitian Program Pascasarjana Universitas Andalas Padang.

SHM. 2000. Prosedur Reagensia Kimia Klinik. PT. Segara Husada Mandiri, Jakarta.

Sopandi T dan Wardah. 2014. Mikrobiologi Pangan ( teori dan praktik ). Penerbit Andi. Yogyakarta.

Trisna, W. N. 2012. Identifikasi Molekuler dan Pengaruh Pemberian Probiotik Bakteri Asam Laktat (Bal) Asal Dadih dari Kabupaten Sijunjung Terhadap Kadar Kolesterol Daging Pada Itik Pitalah Sumber Daya Genetik Sumatera Barat. Artikel. Program Pascasarjana Universitas Andalas, Padang. $32 \mathrm{hlm}$.

Witantra. 2011. Pengaruh Pemberian Lisin dan Metionin Terhadap Persentase Karkas dan Lemak Abdominal pada AyamPedaging Asal Induk Bibit Mudadan Induk Bibit Tua. Artikel Ilmiah. Universitas Airlangga. Surabaya. 